\title{
Shrubs and Degraded Permafrost Pave the Way for Tree Establishment in Subarctic Peatlands
}

\author{
Juul Limpens, ${ }^{1 *}$ Thijs P. M. Fijen, ${ }^{1}$ Iris Keizer, ${ }^{1}$ Johan Meijer, ${ }^{1}$ \\ Fanny Olsthoorn, ${ }^{1}$ Ana Pereira, ${ }^{1}$ Roel Postma, ${ }^{1}$ Mariette Suyker, ${ }^{1}$ \\ Harri Vasander, ${ }^{2}$ and Milena Holmgren ${ }^{1 *}$
}

${ }^{1}$ Department of Environmental Sciences, Wageningen University, Droevendaalsesteeg 3a, Building 100, 6708 PB Wageningen, The
Netherlands; ${ }^{2}$ Peatland Ecology Group, Department of Forest Sciences, University of Helsinki, P.O. Box 27, o0014 Helsinki, Finland

\section{Abstract}

Arctic and subarctic ecosystems are changing rapidly in species composition and functioning as they warm twice as fast as the global average. It has been suggested that tree-less boreal landscapes may shift abruptly to tree-dominated states as climate warms. Yet, we insufficiently understand the conditions and mechanisms underlying tree establishment in the subarctic and arctic regions to anticipate how climate change may further affect ecosystem structure and functioning. We con-

Received 19 December 2019; accepted 3 June 2020; published online 30 June 2020

Electronic supplementary material: The online version of this article (https://doi.org/10.1007/s10021-020-00523-6) contains supplementary material, which is available to authorized users.

Authors Contributions JL and MH conceived, designed, performed, analysed and wrote. TF analysed and commented text. IK, JM, FO, AP, RP, MS performed, analysed and commented text. HV designed and commented text.

*Corresponding author; e-mail: Juul.Limpens@wur.nl

Milena.Holmgren@wur.nl ducted a field experiment to assess the role of permafrost presence, micro-topography and shrub canopy on tree establishment in almost tree-less subarctic peatlands of northern Finland. We introduced seeds and seedlings of four tree-line species and monitored seedling survival and environmental conditions for six growing seasons. Our results show that once seedlings have emerged, the absence of permafrost can enhance early tree seedling survival, but shrub cover is the most important driver of subsequent tree seedling survival in subarctic peatlands. Tree seedling survival was twice as high under an intact shrub canopy than in open conditions after shrub canopy removal. Under unclipped control conditions, seedling survival was positively associated with dense shrub canopies for half of the tree species studied. These strong positive interactions between shrubs and trees may facilitate the transition from today's treeless subarctic landscapes towards tree-dominated states. Our results suggest that climate warming may accelerate this vegetation shift as permafrost is lost, and shrubs further expand across the subarctic.

Key words: alternative ecosystem states; boreal ecosystems; climate change; plant facilitation; permafrost; resilience; tree-line expansion; vegetation shifts; woody plant encroachment. 


\section{HighLIGHTS}

- We assessed the mechanisms underlying tree expansion in subarctic peatlands.

- Tree establishment increased with permafrost absence and shrub cover presence.

- Subarctic peatlands may transition towards treedominated states with climate warming.

\section{INTRODUCTION}

Climate warming of arctic and subarctic ecosystems is advancing twice as fast as the global average (IPCC 2019). This induces changes in species' distributions and ecological processes that could further reinforce climate warming through a series of positive feedbacks that remain very poorly understood. Progressive melting of once permanently frozen soils has resulted in degraded permafrost layers across North America, Europe and Asia (Payette and others 2004; Åkerman and Johansson 2008; Mamet and others 2017; Biskaborn and others 2019). Permafrost degradation facilitates organic matter decomposition and the release of stored soil carbon as carbon dioxide $\left(\mathrm{CO}_{2}\right)$ and methane $\left(\mathrm{CH}_{4}\right)$ (Goulden and others 1998; Betts 2000; Schuur and others 2015). This can be particularly relevant for permafrost peatlands that store approximately $14 \%$ of the global soil carbon (Malmer and others 2005; Tarnocai and others 2009; Olefeldt and others 2016). Higher decomposition rates also increase plant-available nitrogen which, combined with warmer temperatures, can stimulate faster plant growth and species turn-over (Jorgenson and others 2001; McGuire and others 2006; Wang and others 2017). Indeed, northward expansion of shrub and tree lines has been correlated with climate warming (Rupp and others 2000; Chapin and others 2005; Tape and others 2006; Myers-Smith and others 2015; García Criado and others 2020). In turn, woody plant canopies trap thicker snow layers than herbaceous plants, and because snow insulates the soil more effectively, this results in higher soil temperature and enhanced microbial activity that may further enhance decomposition rates and woody plant expansions (Sturm and others 2005; Zhang and others 2013; Hagedorn and others 2014).

However, melting of permafrost due to climate warming could also suppress, instead of stimulate, the recruitment of shrubs and trees. The establishment success of shrubs and trees on degraded permafrost can be limited since anoxic conditions in poorly drained, waterlogged soils, can drastically limit root growth and survival (Lloyd and others 2003). This mechanism has been proposed to explain past vegetation shifts in permafrost peatlands (Swindles and others 2016) and shrub mortality on patches of melted permafrost in arctic tundra (Nauta and others 2015). However, as long as roots do not become waterlogged, shrubs can survive in very thin aerobic layers with a depth of a few centimetres. Under these wet conditions, shrubs may act as nurse plants for trees. Experimental evidence in wet boreal peatlands shows that shrubs can indeed facilitate tree seedling establishment by ameliorating stressful abiotic conditions (Holmgren and others 2015). These facilitative interactions between plants can potentially generate positive feedbacks that may shift ecosystems towards more densely vegetated states (Kéfi and others 2016). Interestingly, discontinuities in tree cover distribution across boreal ecosystems suggest the existence of critical transitions between treeless landscapes, open woodlands and forests (Scheffer and others 2012; $\mathrm{Xu}$ and others 2015). Yet the mechanisms explaining these abrupt vegetation changes remain elusive.

Most of our knowledge on successional trajectories in boreal ecosystems relies on field, and remotely sensed observations. Yet, to unravel the mechanisms that explain woody plant expansion we need field experiments assessing the relative importance of the hypothesised ecological processes. In this paper, we report on a long-term field experiment aiming to understand the mechanisms that could facilitate tree expansion on currently almost tree-less permafrost peatlands at the southern edge of the permafrost distribution which is most vulnerable to climate warming (Sollid and Sørbel 1998; Luoto and Seppälä 2003; Fronzek and others 2010). This subarctic region is characterised by peatlands in wet and cold depressions, whereas the drier upland sites are covered by stunted mountain birch forest or alpine heath. The extremely wet environment of peatlands with its small-scale topography offers a good opportunity to study mechanisms underlying tree survival and expansion under poorly drained conditions, and, therefore, also provide a glimpse of how tree expansion may proceed as permafrost disappears.

We followed a field experiment designed to assess how permafrost presence, micro-topography and shrub canopy affect tree seedling germination and survival during six growing seasons. We hypothesised (1) tree seedling establishment to be more successful with lower abiotic stress, and, therefore, (2) expected higher seedling survival 
without permafrost, on sheltered topographic positions, and under an intact shrub canopy.

\section{Materials ANd Methods}

\section{Study System and Sites}

Field experiments were conducted in two permafrost peatlands about $37 \mathrm{~km}$ apart within the discontinuous permafrost zone of subarctic Finnish Lapland: a northern site Pulmankijärvi $\left(70^{\circ} 02^{\prime} \mathrm{N}\right.$, $27^{\circ} 53^{\prime} \mathrm{E} ; 142$ m.a.s.l.) and a southern site Skalluvaara $\left(69^{\circ} 49^{\prime} \mathrm{N}, 27^{\circ} 09^{\prime}\right.$ E; 239 m.a.s.l. $)$ (Figure la).

Subarctic permafrost peatlands are characterized by a small-scaled topography of elevated microsites (hummocks) within an overall waterlogged environment. On the sides of, and in between, the hummocks, the soil moisture content is high, whereas the tops are drier and more exposed to harsh, cold, and windy conditions (Holtmeier and
Broll 2007; Anschlag and others 2008). All hummocks in the study areas freeze during winter and thaw from the top down during spring. However, some hummocks thaw completely, whereas others keep a frozen core throughout the growing season. In hummocks with a frozen core, soil temperature, available rooting depth, and nutrient mineralisation are expected to be low (Waelbroeck and others 1997; Schuur and others 2007), presumably acting as a strong environmental filter against tree recruitment.

Our two study peatlands are characterised by small raised topographic patches about 1-2 $\mathrm{m}$ high and a diameter of $2 \mathrm{~m}$, embedded in an overall wet matrix dominated by the peat moss Sphagnum jensenii, and with a water table within $10 \mathrm{~cm}$ of the surface (Figure $1 \mathrm{~b}$ ). The raised patches are referred to as "pounu" in the Finnish literature (Luoto and Seppälä 2002), or as hummocks in general peatland terminology and this paper. The hummocks at both experimental sites are characterised by low shrubby
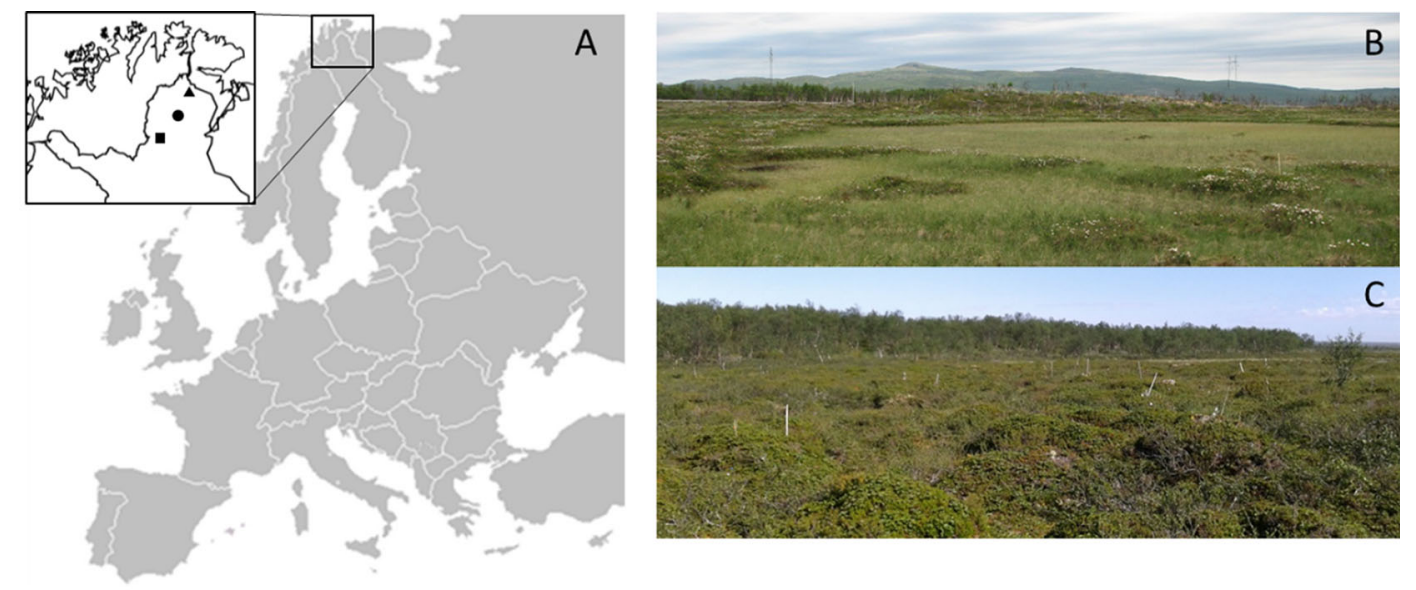

METEOROLOGICAL CONDITIO
Annual Temperature $\left({ }^{\circ} \mathrm{C}\right)$
Summer T (July-August)
Winter T (Dec-Feb)
Annual Precipitation (mm)
Summer P
Winter P
Snow cover (days)
Snow depth (cm)

Mean
0.2
12.4
-11.2
446
134
83
197
42

Min
-0.6
5.2
-37.8
387
74
49
181
8

Max
0.7
25.7
3.2
539
226
111
211
83

LTA
-0.4
12.0
-11.2
441
126
83
$N / A$
42

Figure 1. Sites and climate. A Location of Kevo Subarctic Research Station (square) and experimental sites in Finnish Lapland: northeastern site Pulmankijärvi (triangle) and southern site Skalluvaara (circle). B Overview of Pulmankijärvi. C Overview of Skalluvaara. D Meteorological conditions (mean, minimum and maximum) for the study area during experimental period (2014-2019). Data were obtained from the Finnish Meteorological Institute (https://en.ilmatieteenla itos.fi/); from the Kevo Subarctic Research Station (ID: 102035. Coordinates: 69.75637; 27.00678) and the Nuorgam Observation Station, which is close to Pulmankijärvi (ID: 102036. Coordinates: 70.08203; 27.89650). LTA = long-term average 1989-2019. Snow cover days are between November-May. Snow depth data refer to midwinter (DecemberFebruary) when temperatures are the lowest. $-=$ missing data. 


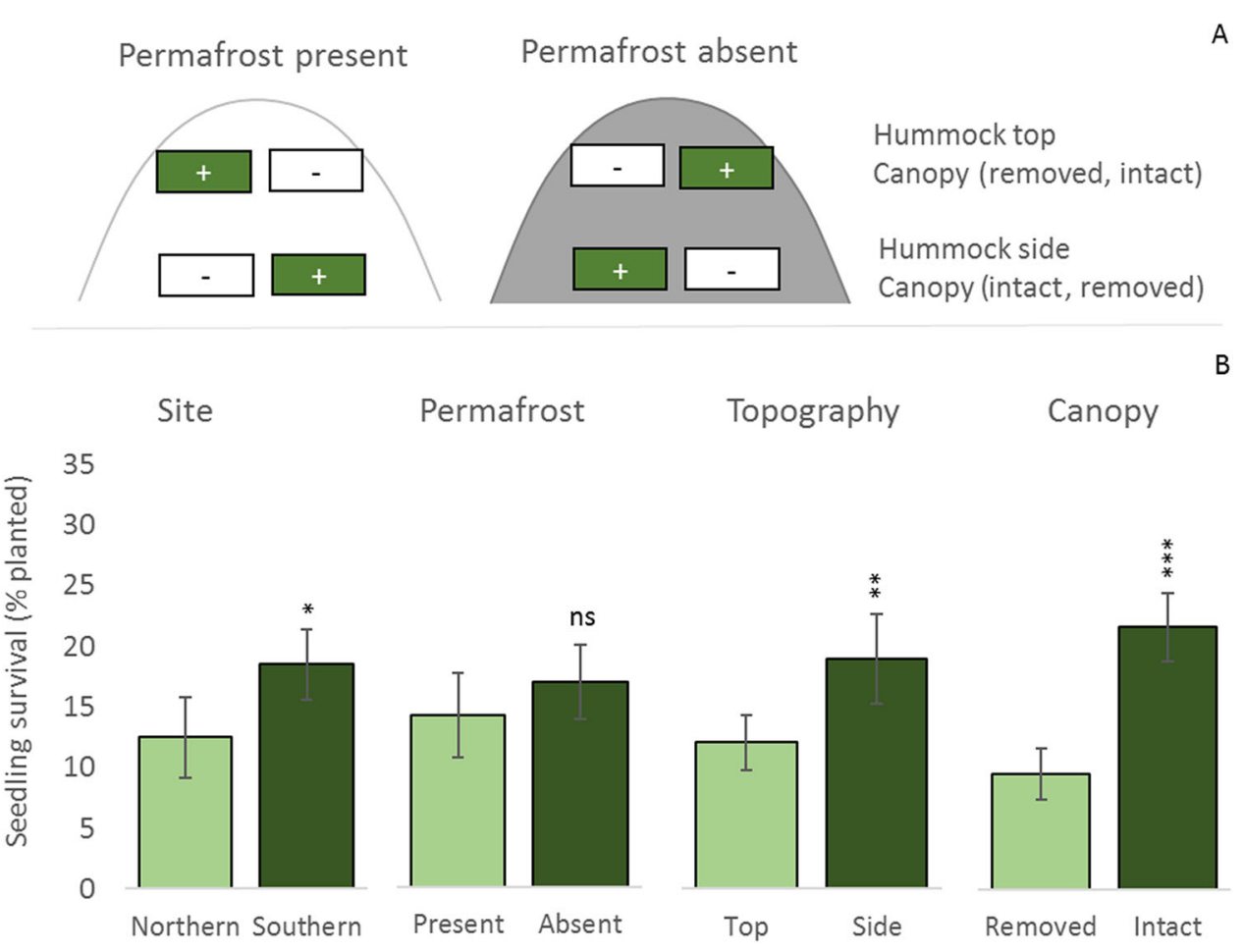

Figure 2. Experimental design and tree seedling survival. A Position plots where tree seedlings were planted: hummocks with contrasting permafrost presence (present, absent, $n=30$ ), topographic positions (hummock top, hummock side, $n=60$ ) and shrub canopy treatments (intact + , removed,$- n=120$ ). B Survival (mean, \pm 1 SE) of planted seedlings after six growing seasons in response to site (northern site Pulmankijärvi, southern site Skalluvaara), permafrost presence, (micro)topography and shrub canopy. Seedling survival has been expressed as \% of the seedlings planted (60) in the 16 unique site * microsite * treatment combinations. For statistical analyses see Table 2 . For statistical analyses of cumulative seedling survival per time-interval see Table S3 and for survival per tree species see Table S4.

vegetation of about $10-30 \mathrm{~cm}$ in height (Andromeda polifolia, Betula nana, Empetrum nigrum, Ledum palustre, Rhododendron tomentosum and Salix glauca) along with the many Vaccinium dwarf shrub species, including $V$. microcarpum, V. myrtillus, V. uliginosum and $V$. vitis-idaea and the commonly occurring boreal herb Rubus chamaemorus. Occasionally, seedlings and saplings of tree species $B e-$ tula pubescens ssp. czerepanovii and Pinus sylvestris occur on the hummocks. For more detailed site descriptions, we refer to Luoto and Seppälä (2002).

Over the experimental period (2014-2019), the mean annual temperature at the study sites ranged between $-0.7{ }^{\circ} \mathrm{C}(2017)$ and $0.7{ }^{\circ} \mathrm{C}(2015,2016)$ (Figure 1). Mean annual precipitation ranged between $387 \mathrm{~mm} \mathrm{(2014)}$ and $539 \mathrm{~mm}$ (2017). About $50 \%$ of the precipitation falls in the form of snow (Merkouriadi and others 2017), ranging between 181 and 211 days of snow cover annually between early October until the end of May for the experimental period. Although climate conditions between sites are comparable, differences in landscape features between sites mediate the harshness of the abiotic conditions experienced locally by the vegetation. The northern site has a more open, and thus a more wind exposed, landscape than the southern site. The higher wind exposure translates into cooler conditions in summer and winter. For example, inhabitants of the region agree that snow covers are thinner in the vicinity of the northern site Pulmankijärvi than in the vicinity of southern Skalluvaara. Indeed, snow depth in the peatland near Pulmankijärvi (34 $\pm 1 \mathrm{~cm}, n=30$ ) was almost half that of the peatland near Skalluvaara $(59 \pm 2 \mathrm{~cm}, n=30)$ in the winter of 2019.

\section{Experimental Design}

At each site we conducted a field experiment with a nested factorial design using hummocks as our experimental units to assess the effects of permafrost presence, micro-topography and shrub cover on tree seedling germination and survival. Shrub cover was nested within micro-topographical position, which both were nested within hum- 
mock (Figure 2A). As our tree species, we chose four species that form the treelines in subarctic Finland and west Siberia north of the $68^{\circ} \mathrm{N}$ line (Hustig 1953): Larix sibirica (Siberian larch), Pinus sylvestris (Scots pine), Picea abies (Norway spruce), and Betula pubescens ssp. czerepanovii (Mountain birch). Betula pubescens was the dominant tree species on the mineral outcroppings surrounding the peatlands. Betula and Pinus were the only tree species that had naturally established on the peatlands under study, albeit at low density.

In early July 2014, we selected 30 hummocks at each site: 15 with a frozen core (probed with a thin, $90 \mathrm{~cm}$ long, metal rod; see below) and 15 without a frozen core, respectively, referred to as hummocks with and without permafrost. On each of the hummocks we established four plots of $40 \times 20 \mathrm{~cm}$, resulting in a total of 120 plots per site. Two paired plots on the top of the hummock, and two paired plots at the hummock base exposed towards the south. The low topographical position is from here on referred to as the hummock side. Plot pairs had homogeneous vegetation and were spaced $20-40 \mathrm{~cm}$ apart. In one randomly selected plot of each pair, plants were clipped at the beginning of the experiment, leaving the insulating moss and peat layers undisturbed. Clippings were collected and weighed after drying for $48 \mathrm{~h}$ at $70{ }^{\circ} \mathrm{C}$ to assess aboveground plant biomass. Re-sprouting non-target plants were clipped again at the onset of the growing season in the year 2015 after assessing climate and soil conditions (see measurements).

Within each plot, we introduced (i) five seeds per tree species on top of the soil surface in a small depression and (ii) one small seedling $(2-5 \mathrm{~cm}$ tall; 2 months old) per tree species for larch, pine and spruce, following the experimental protocol used earlier in boreal peatlands (Holmgren and others 2015). For birch we used 10 seeds and a seedling of the same height $(2-5 \mathrm{~cm}$ tall; 1 year old $)$ as seed quality was low and 2-month-old seedlings were too small and fragile to survive transplantation. To plant all seedlings, we made a 10 -cm-deep incision in the moss-soil surface, gently introduced the seedling and pressed the sides of the surface back (Limpens and others 2014). All seedlings were well-watered prior to planting. Coniferous seeds were from arctic provenance and came from a commercial nursery in Rovaniemi, a town situated at the arctic circle. Birch seeds were collected near the Kevo Subarctic Research Station in autumn 2013. After establishing the field experiment, seed viability was assessed under optimal light, temperature and moisture conditions using 40 seeds per species for spruce, pine and larch and 80 seeds for birch. Seedling emergence success after 15 days was $100 \%$ for spruce, $97.5 \%$ for pine, $70 \%$ for larch and $1.3 \%$ for birch. Experimental seedlings were pre-grown on non-fertilised potting compost at ambient temperature at the Kevo Subarctic Research Station. Field experiments in both sites were installed in early July 2014 and monitored during the growing seasons in 2014, 2015, 2016 and 2019.

\section{Emergence and Survival of Seedlings}

Emergence of seedlings from planted seeds was determined annually for three growing seasons after seeding. Multiple emerged seedlings from the same species were labelled individually. Emergence of seedlings from seeds was too sporadic to be analysed statistically. Instead we report percentage of emerged seeds per species per site in the results only. Survival of planted seedlings was determined in the beginning of July and end of August for both 2014 and 2015. In 2016 and 2019 we monitored survival only at the end of August, as mortality within season was no longer significant in 2015 . Planted seedlings were considered dead if $100 \%$ of the needles or leaves were brown and never recovered, or if the seedling was missing during subsequent surveys. Height of planted seedlings was measured in July 2014 and August 2019.

\section{Environmental Conditions}

Environmental conditions were monitored in detail during the first two growing seasons, a period considered critical for seedling establishment in plant communities (Crawley and Ross 1990).

To test if vegetation characteristics differed between the investigated microsites, we assessed species abundance using the point intercept method on a $5 \times 5 \mathrm{~cm}$ grid (21 interceptions) suspended over each plot in 2014. At all intersections, a needle was lowered perpendicular to the soil surface and all species touched by the needle were recorded; multiple hits of the same species at the same point did not count. The data were used to calculate total number of species, percentage cover of woody and herbaceous species, and total cover. Vegetation height was measured per plot using a ruler.

Permafrost presence was recorded, and the depth of the unfrozen layer (active layer depth) was measured with $1 \mathrm{~cm}$ accuracy in two locations per hummock: in between the paired plots on top of the hummock and in between the paired plots on the side of the hummock. To this end, a thin metal rod was pushed vertically into the soil until $90 \mathrm{~cm}$ depth or until resistance by frozen soil was met. 
These measurements were taken in week three of July 2014, July 2015 and August 2015 to explore consistency of permafrost presence between years and within growing season. Permafrost presence changed in five out of 60 hummocks between July 2014 and July 2015, but did not change within growing season (July 2015 vs. August 2015). To check if this change affected the results, we ran all statistical models twice, once with permafrost presence in July 2014 and once with permafrost presence in July 2015. As this did not affect the results, we used permafrost presence of July 2014 in all models reported in this manuscript.

Soil temperature $\left({ }^{\circ} \mathrm{C}\right)$ was measured at the centre of each experimental plot using a soil thermometer (Traceable ${ }^{\circledR}$ ) at $20 \mathrm{~cm}$ depth (2014) and $12.5 \mathrm{~cm}$ depth (2015) a few days after the shrub canopy removal in the third week of July (2014) and August (2015). Measured soil temperature of both years showed similar patterns across the two depths. To explore winter soil temperature, we inserted temperature loggers (iButtons ${ }^{\mathrm{TM}}$ ) at a depth of five $\mathrm{cm}$ on tops of two adjacent hummocks contrasting in permafrost presence (presence, absent) between October 2014 and May 2015 and at contrasting topography (top, side) under an intact canopy between December 2015 and August 2016.

Soil moisture (volumetric \%) of the top five $\mathrm{cm}$ soil was measured at four positions per plot using a theta probe (ML2x, Delta-T Devices) a few days after the shrub canopy removal in the third week of July (2014) and August (2015). Rainfall was absent on the days before and during the measurements.

Irradiance was measured above each seedling using a photosynthetic active radiation sensor (PAR sensor, Skye Instruments) under overcast conditions in the second and third week of August 2015. To enable the best comparisons between unclipped and clipped plots per tree species, we measured irradiance consecutively in the plot with and without shrubs just above the seedlings of each species.

To assess if presence of permafrost modified nutrient availability in the top soil layer, we measured availability of main soil nutrients $(\mathrm{N}, \mathrm{P}, \mathrm{K})$ using cotton bags containing ion exchange resin in 2014 and 2015. This method has been successfully used before to assess contrasts in plant-available nutrients (Qian and others 1992; Hobbie and Chapin 1998; Holmgren and others 2015). Each bag was filled with $1 \mathrm{~g}$ of ion exchange resin and closed with a clip. A piece of white string was attached to the clip to facilitate locating them. Per hummock, one resin bag was inserted $10-20 \mathrm{~cm}$ (2014) and 5-10 cm (2015) into the soil between the two top plots after making an incision with a sharp knife. The bags were in full contact with the soil for 3 weeks between the third week of July and the third week of August in both 2014 and 2015, after which they were removed, air-dried and transported to the Netherlands. At Wageningen University, the bags were cleaned from roots, soil and dirt and dried for $48 \mathrm{~h}$ at $25^{\circ} \mathrm{C}$. The resins were weighed and $50 \mathrm{~mL} 2 \mathrm{M} \mathrm{NaCl}$ in $0.1 \mathrm{M} \mathrm{HCl}$ was added. The mixture was shaken for $2 \mathrm{~h}$ and nitrate, ammonium, phosphorus (P) and potassium (K) concentrations were measured in a continuous flow analyser (SKALAR SAN Plus system). Concentrations of ammonium and nitrate were summed into nitrogen $(\mathrm{N})$ availability.

\section{Statistical Analysis}

To check whether vegetation characteristics and microclimate differed between our treatments and between sites, we used linear mixed models (function 'lmer' in R-package lme4; Bates and others 2015). We averaged all variables per microsite and per year, if applicable. We explored the four- and three-way interactions between treatments (site, permafrost, microtopography, and shrub canopy cover); however, none were significant and were further excluded for simplicity. We constructed models using all possible two-way interactions, and stepwise removed non-significant interactions, until only significant interactions and all main effects remained. Analysing the data separately for each site did not change results (Table S2B and S2C), so we present the results here based on the full dataset. As our random structure we used hummock ID, nested within site, to correct for dependencies between measurements within the four plots of a hummock. Analysing the effect of our treatments on the number of plant species using a Poisson or negative-binomial distribution resulted in severe under-dispersion. Because the number of plant species followed a normal distribution and the fit was good, we assumed a normal distribution. To improve the normality of the residuals, we needed to square-root transform herbaceous plant cover, total vegetation cover, aboveground plant biomass, and soil moisture, quadratic-transform woody plant cover, and $\log 10$ transform the vegetation height and irradiance. In the tables we report untransformed data.

As soil measurements $(\mathrm{N}, \mathrm{P}$ and $\mathrm{K}$ concentrations) were only measured per hummock, we tested potential differences in nutrients between hummocks with and without permafrost and between sites. We used the same approach as above, 
but with simpler models ( $\mathrm{lm}$ ) using only permafrost, site and their two-way interaction. We $\log 10$-transformed N, P and K to improve normality of residuals. For $\mathrm{N}$ and $\mathrm{P}$ we removed one extreme outlier, and for $\mathrm{K}$ two extreme outliers, as their values were at least seven times larger than the mean.

We analysed the survival of planted tree seedlings using generalised linear mixed models (function 'glmer' in R-package lme4) with a logit-link function, assuming a Bernoulli distribution (1 being alive, 0 being dead). Our dataset did not allow for tests with four-way interactions, but instead we assessed all possible two- and three-way interactions for the full dataset (including site and tree species as fixed effect), and for separate datasets per site (Table S3), and per tree species (Table S4), as this could indicate whether threeway interactions would differ with site or tree species. However, none of the two- and three-way interactions were significant. We therefore used only main-effect models for each survival analyses on the full dataset. We used site, permafrost, microtopography, shrub canopy cover, and tree species as our explanatory variables, and hummock ID nested within site as our random structure. We tested the following four periods in separate analyses to assess if factors driving cumulative seedling survival would remain consistent through time: July 2014-August 2014, July 2014-August 2015, July 2014-August 2016 and July 2014-July 2019.

To further explore the effect of shrub canopy removal on seedling survival, the strongest driver in our study, we summed all the seedlings surviving after 6 years for each treatment per site (that is, maximum of four survivors per plot). The strength of this canopy effect was illustrated with $X^{2}$ tests for each micro-topographic position per site, with and without permafrost. The high between-hummock variation in survival and the low survival over the 6 years, left us with too few degrees of freedom to support a more complex analysis that takes into account the random structure: thus the $X^{2}$ results should be interpreted with caution.

To test whether early seedling survival (2014, 2015) differed with microclimate and soil nutrients we used generalised linear mixed models (glmer) with hummock ID nested within site as our random structure. Additionally, effects of vegetation characteristics (biomass and vegetation cover) were tested only on microsites with the shrub canopy intact and for survival within 2014. To analyse this, we used generalised linear models (glm), where we assumed that biomass and vegetation cover in those plots was similar to the biomass and vegetation cover from the adjacent canopy removal plots. We performed these analyses separately for each tree species. Variables were scaled before these analyses.

$P$ values were obtained using a likelihood ratio test. All analyses were carried out in $\mathrm{R}$ 3.6.1 (R Development Core Team 2019).

\section{RESUltS}

\section{Environmental Conditions}

Microclimates in hummocks with and without permafrost were different irrespective of study site. In the summer, soil temperature was between one and two degrees warmer in hummocks without permafrost than in hummocks with permafrost (Table 1, Table S2). This difference was larger in the winter, where the minimum winter soil temperature was six degrees warmer in the hummock without permafrost compared to hummocks with permafrost. Within hummocks, soil temperature differed between topographic positions mostly in the winter: the minimum soil temperature at the side of a hummock was three degrees warmer than on the top. In contrast, during the summer the sides of the hummock were slightly cooler than the tops. The removal of the shrub canopy did not significantly affect summer soil temperature. Soil moisture was not significantly affected by permafrost condition or shrub canopy removal, but was significantly higher on hummock sides than on hummock tops. (Table 1, Table S2).

Hummocks without permafrost tended to have higher maximum concentrations of nitrogen, phosphorus and potassium irrespective of site. However, the effect of permafrost was not statistically significant to explain differences in nutrient concentration $(\operatorname{Pr}(>|t|)>0.05)$ likely as result of high between-hummock variation (Table 1, Table S2). Nutrient availability did not differ significantly between study sites, except for nitrogen, which was slightly higher at the northern site (Table 1, Table S2A).

The overall plant species richness on the hummocks was comparable between sites (Table S1). Absence of permafrost increased the number of species, but had no statistically significant effects on biomass or vegetation height. Within hummocks, the sides had a higher vegetation cover, taller vegetation and were richer in species than hummock tops (Table 1, Table S2). 


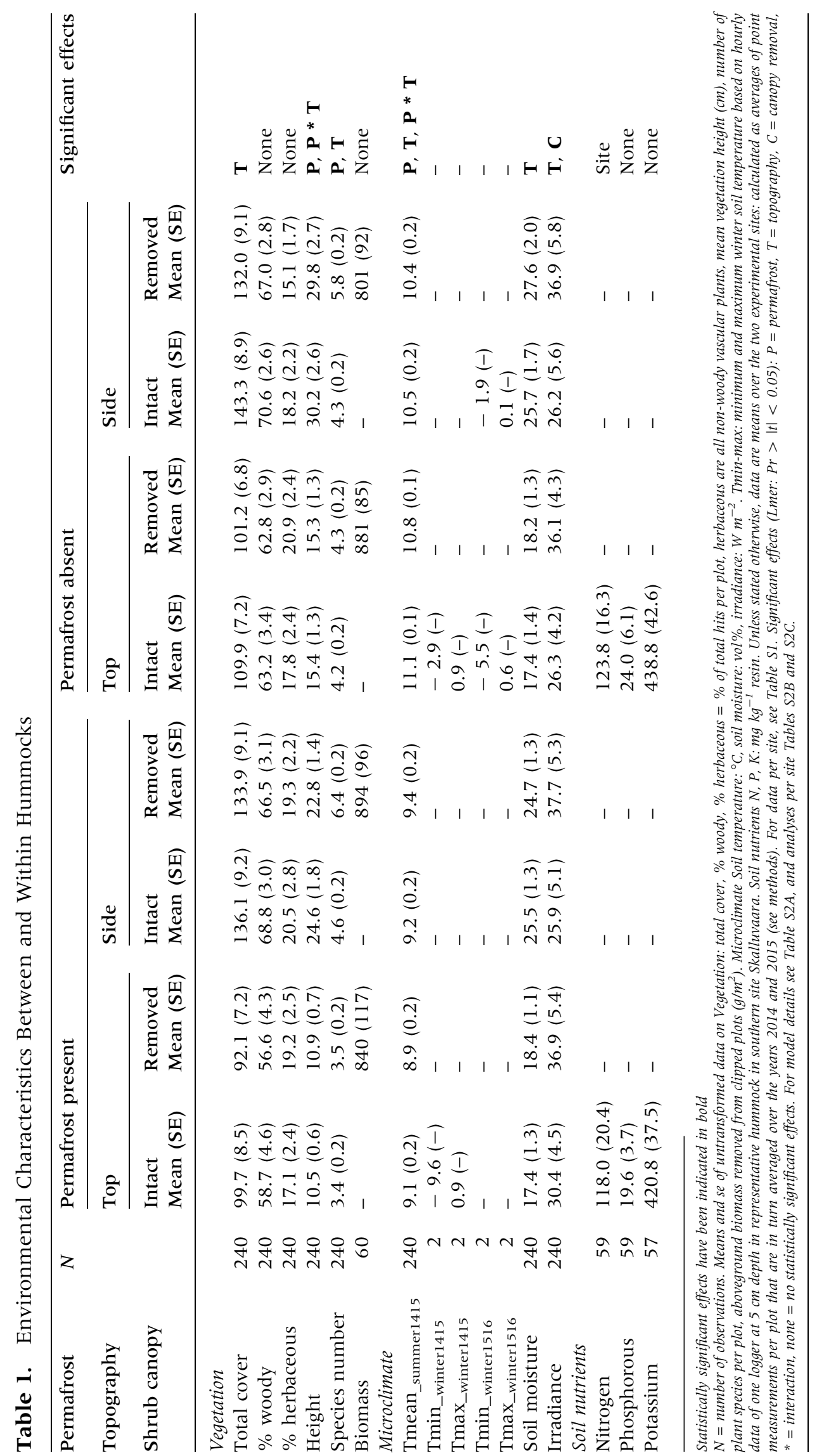




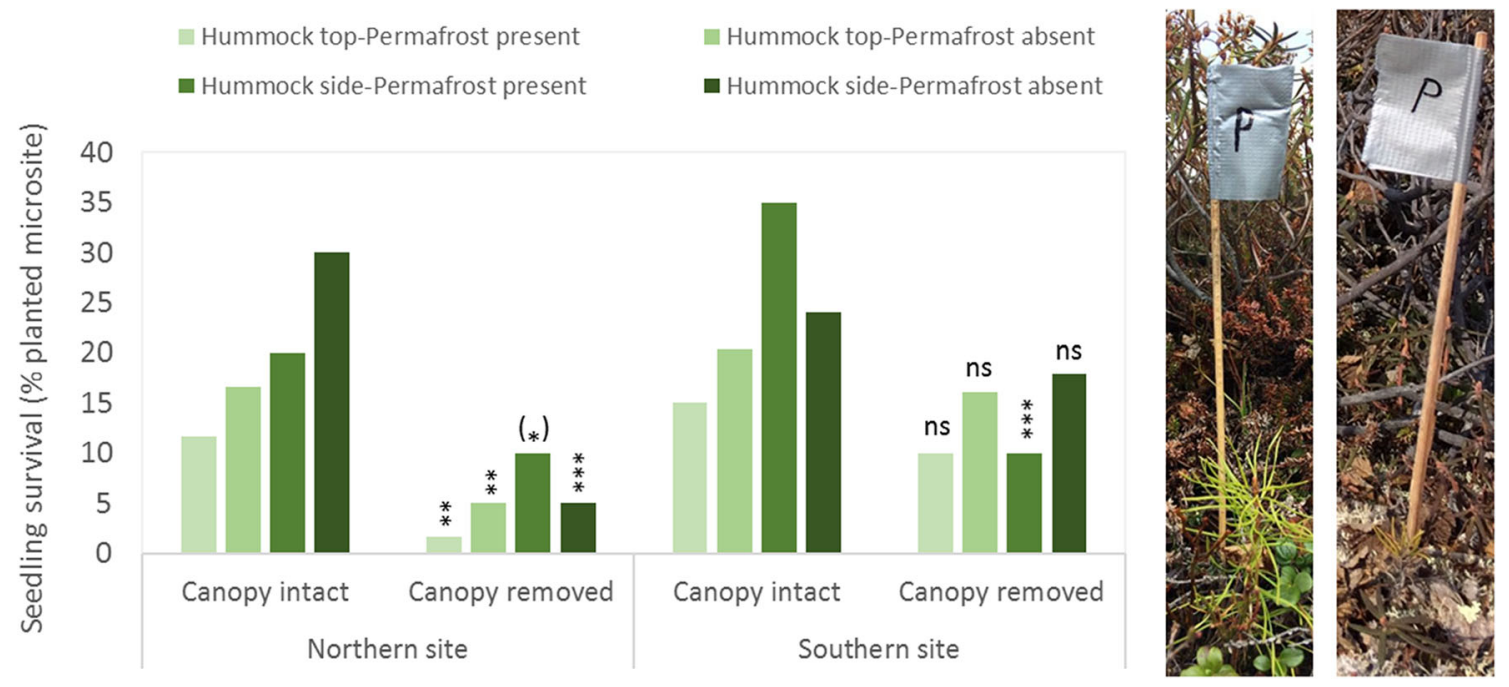

Figure 3. Shrub canopy effects on tree seedling survival in the four microsites per site distinguished in this study: tops and sides of hummocks with and without presence of permafrost. Bars represent tree seedling survival after six growing seasons. Seedling survival has been expressed as \% of the seedlings planted (60) in the 16 unique site * microsite * treatment combinations shown. Statistically significant effects of shrub canopy presence are indicated for each microsite. ns $=P \geq 0.10,\left(^{*}\right)=0.05<P<0.10,{ }^{* *}=0.01<P<0.001,{ }^{* *}=P<0.001$, $\mathrm{X}^{2}$-test. Picture inset shows seedlings of pine under a canopy (left) and outside a shrub canopy (right) for a hummock top with permafrost at the northern site.

\section{Tree Seedling Emergence and Survival}

Emergence from seeds was less than $10 \%$ for all tree species irrespective of site. Seedling emergence ranged between 1.7 and $9.8 \%$ for the conifers (larch, pine and spruce) and was unsuccessful for birch. Conifer emergence was higher at the northern site $(7.2-9.8 \%)$ than at the southern site $(1.7-6.5 \%)$, particularly for Larch $(1.7 \%$ southern site vs. $9.8 \%$ northern site). One year later, survival of these emerged seedlings was only $1.2 \%$ for larch, $1.4 \%$ for spruce and $4.5 \%$ for pine taken over both sites together. After six growing seasons, only two spruce seedlings that had emerged from seeds were still alive in the whole experiment, both at the northern site.

Survival of planted seedlings was highest in the southern site Skalluvaara. After 6 years, $18 \%$ of all seedlings planted survived in the southern site, whereas $13 \%$ survived in the northern site. Despite the difference in overall seedling survival between sites, patterns across species and microsites were comparable between the two experimental sites (Table S4). After six growing seasons, larch seedlings survived least $(1$ and $3 \%$ for southern and northern site, respectively), whereas pine $(34 \%$ vs. $14 \%)$ and spruce had the highest survival ( $26 \%$ vs. $19 \%$ ). Mountain birch took an intermediate position, with survival being $13 \%$ irrespective of site.
Table 2. Effects of Permafrost, Topography, Shrub Canopy and Tree Species on Cumulative Tree Seedling Survival

\begin{tabular}{lrrrrr}
\hline Glmer & $N$ & \multicolumn{3}{l}{ July 14-Aug 19 } & \\
\cline { 3 - 6 } & & Estimate & SE & $Z$ & Pr $>|z|$ \\
\hline Intercept & & -1.48 & 0.31 & -4.78 & $<\mathbf{0 . 0 0 1}$ \\
Site & 2 & 0.58 & 0.26 & 2.24 & $\mathbf{0 . 0 3}$ \\
Permafrost & 60 & -0.23 & 0.26 & -0.90 & 0.37 \\
Topography & 120 & -0.66 & 0.20 & -3.27 & $\mathbf{0 . 0 0 1}$ \\
Shrub canopy & 240 & -1.15 & 0.21 & -5.48 & $<\mathbf{0 . 0 0 1}$ \\
Tree species & & & & & $<\mathbf{0 . 0 0 1}$ \\
Spruce & 240 & 0.76 & 0.26 & 2.90 & $\mathbf{0 . 0 0 4}$ \\
Larch & 240 & -2.06 & 0.50 & -4.14 & $<\mathbf{0 . 0 0 1}$ \\
Pine & 240 & 0.84 & 0.26 & 3.24 & $\mathbf{0 . 0 0 1}$ \\
& & & & &
\end{tabular}

Statistically significant effects have been indicated in bold

Data were analysed with a generalised linear mixed model with site and hummock within site as random factors. Z-values and probabilities indicate significance relative to intercept. Intercept has been set to: northern site

Pulmankijärvi, no permafrost, hummock sides with canopy intact and tree species birch. For separate analyses per site see Table S3 and per tree species per site see Table S4.

Seedling survival differed significantly between microsites, being highest on hummock sides without permafrost, and under shrubs, irrespective of site or species (Figure 2, Table 2). The effects of shrub canopy and microtopographic position in- 
creased in strength over the years, whereas the effect of permafrost disappeared after the first year (Figure 2, Table S3).

Early survival over the first summer was significantly higher for all conifers than for birch; however, conifer mortality was high during the first winter (August 2014-July 2015, data not shown), evening out the species specific differences in survival built up over the first growing season. Over the following years survival of larch declined stronger than that of pine, spruce and birch, leading to a significantly lower survival of larch relative to the other species in 2019 (Tables S3, S4).

After six growing seasons of the field experiment, tree seedling survival under the shrub canopy was consistently higher than outside the shrub canopy, irrespective of site, microsite, or tree species (Figure 3, Table S4). This shrub canopy effect was strongest for the top of hummocks with permafrost in the northern site where seedlings under the shrub canopy survived seven times better than seedlings outside the shrub canopy. In contrast, on the sides of frozen hummocks, shrub presence only doubled the survival of seedlings, with a comparable effect size between sites. Shrub canopy also had a positive effect on hummocks without permafrost, especially at the northern site. Here the facilitative effect of shrubs on seedling survival was more than three times larger than at the southern site, for both tops and sides.

Height growth of the surviving seedlings after six growing seasons varied between 0 and $6.8 \mathrm{~cm}$ depending on microsite and species (spruce: $2.6 \mathrm{~cm}$, birch: $6.8 \mathrm{~cm}$, larch: $4.8 \mathrm{~cm}$, pine: $2.5 \mathrm{~cm}$ on average). Seedlings grew tallest under the shelter of shrubs on sides of frozen hummocks at the southern site (Table S5).

We assessed the potential direct effect of environmental conditions on early seedling survival for each species separately. Soil moisture had a consistent positive effect on survival in 2014, and for birch and pine in 2015. Nitrogen had a negative effect on survival in 2015 for birch and pine. The only other significant effect was that soil temperature increased larch seedling survival in 2014 (Table S6).

\section{Discussion}

Our field experiments identified key mechanisms that could facilitate tree expansion on currently almost tree-less subarctic peatlands. We found tree establishment in subarctic permafrost peatlands to be strongly constrained under current environmental conditions. Rates of seedling emergence and seedling survival were low. Only $7 \%$ of the inserted seeds emerged of which $0.5 \%$ survived until the sixth growing season of our study. Of the planted seedlings $16 \%$ survived until the end of our study. These patterns show that seedling emergence and survival are strong bottlenecks for tree recruitment. Our findings are in line with those of Hobbie and Chapin (1998) in tussock tundra.

The tree seedling emergence rates that we found in subarctic permafrost peatlands are much lower than those reported earlier for relatively warmer, southern boreal peatlands, suggesting that low temperature constrains seedling emergence in the subarctic. For instance, emergence of sown Scots pine (P. sylvestris) reached only $5.6 \%$ in the subarctic permafrost peatlands, whereas it reached $40 \%$ in a comparable 3-year field experiment, with similar number of introduced seeds and seed viability, in southern boreal peatlands (Holmgren and others 2015).

Our field experiment with planted seedlings revealed three consistent patterns that indicate that severe abiotic stress is the most limiting factor for tree seedling establishment in the subarctic: (1) seedling survival of two out of four treeline species was highest at the southern study site, Skalluvaara; (2) within study sites, early seedling survival was highest in hummocks without permafrost for all tree species; (3) within hummocks, seedling survival of all tree species was highest under shrub cover and on the hummock sides, which are the most sheltered microsites. Also the naturally established vegetation was taller and richer in species on hummocks without permafrost and on hummock sides.

Permafrost presence strongly decreased establishment of the tree seedlings during the first year after planting. The cooler soil temperatures in hummocks with permafrost may have affected root growth and the survival of very young tree seedlings (Smith and others 2003). However, after 1 year, the effect of permafrost on survival was set off by the sheltering effect of hummock sides. The higher recruitment of experimental tree seedlings at the hummock sides coincided with an overall higher natural vegetation cover, taller vegetation, and a higher species richness at these locations, suggesting conditions more favourable to plant establishment and growth in general.

Our measurements of microclimate suggest that the microclimate of the hummock sides is more constant and benign than that of the hummock tops. In general, the hummock sides tended to be cooler in summer and warmer in winter (Table 1). 
In summer, the hummock sides were also moister than the tops, particularly in hummocks without permafrost. These patterns are supported by extensive monitoring across different types of ecosystems showing that micro-topographic variation coincides with variation in microclimate: with elevated locations generally showing warmer summer, colder winter temperature, thinner snow covers and drier soils than topographic depressions (Suggit and others 2011).

Tree seedling survival was consistently highest under the protection of a shrub canopy demonstrating that shrub facilitation is a key driver of tree seedling establishment in the subarctic. The experimental removal of the shrub canopy reduced seedling survival. The importance of shrub canopy was even visible in the unclipped control plots, where a larger cover or biomass of the natural vegetation increased survival of planted mountain birch and scots pine seedlings. Shrubs can shelter seedlings by ameliorating stressful abiotic conditions or by reducing the effects of herbivores (Holmgren and others 1997; De Frenne and others 2013; Chen and others 2020). Herbivores, such as reindeer and voles, had access to both study sites, so the positive effect of the shrub canopy may have partly resulted from diminished visibility of tree seedlings to herbivores. Herbivory might also explain some of the differences between species, as the palatable mountain birch had lower survival rates than the unpalatable pine and spruce seedlings. Nevertheless, it seems reasonable to interpret that the facilitative interactions were primarily a result of abiotic stress amelioration by the shrub canopy as the strongest positive effects of shrubs were found in the microsites with harshest abiotic conditions (that is, on top of a hummock with permafrost in the northern site). The ameliorating effect of shrubs on abiotic stress likely combines summer shading (Holmgren and others 2015) and winter snow trapping (Myers-Smith and Hik 2013; Nauta and others 2015) that result in less extreme temperatures compared to open microsites.

The facilitative effect of a shrub canopy on tree seedling establishment we found during average weather conditions in subarctic peatlands was comparable to what we reported earlier during extreme weather conditions for southern boreal peatlands (Holmgren and others 2015). The stronger positive effect of shrubs in these northern permafrost peatlands compared to southern boreal peatlands coincides with the difference in abiotic harshness along the distribution range from boreal to subarctic peatlands (that is, mean annual temperature in subarctic Kevo is $-2{ }^{\circ} \mathrm{C}$ vs. $4.2{ }^{\circ} \mathrm{C}$ in southern boreal Lakkasuo). Taken together, our experimental results suggest that the facilitative effect of shrubs on tree seedling performance in peatlands is stronger in the more stressful abiotic conditions of the subarctic than in the southern boreal range, in line with patterns reported for alpine (Ballantyne and Pickering 2015) and tundra plant communities (Myers-Smith and others 2011).

\section{BROADER IMPLICATIONS}

Finnish Lapland, just like the rest of the subarctic and arctic regions, is predicted to keep warming faster than the global average (IPCC 2019), resulting in rapid degradation and disappearance of permafrost soils (Fronzek and others 2010). In our study sites, absence of permafrost in hummocks coincided with warmer soil temperature, the occurrence of more lush vegetation, and a higher survival rate of young tree seedlings. Warmer soil temperatures are known to increase seed vigour (Graae and others 2008) and speed up seed germination (Hobbie and Chapin, 1998; Sirois 2000; Milbau and others 2009; Walck and others 2011). Indeed, seedling emergence in warmer southern boreal peatlands (Holmgren and others 2015) was higher than the emergence in the subarctic peatlands of our study. Once the strong constraint on tree seedling emergence is eased, seedling survival depends on shrub cover. Warmer soil temperatures have also been associated with the northward and upward expansion of shrubs (Frost and Epstein 2013; Dial and others 2016; Malfasi and Cannone 2020). Given the strong positive interactions between shrubs and trees observed in our study and the rapidly warming subarctic climate, their combined influence could trigger positive feedbacks that facilitate a shift from an open tree-less landscape towards a more tree-dominated woodland landscape (Scheffer and others 2012; Xu and others 2015). Shifts in tree cover states in the subarctic would not only put pressure on species restricted to open conditions for completing their life cycle, such as breeding wader birds (Virkkala and others 2008), but also affect ecosystem functioning in various ways including albedo and carbon feedbacks to climate (Zhang and others 2013; Schuur and others 2015; Loranty and others 2018; Zeh and others 2019), hydrology, and sensitivity to wildfires (Mack and others 2011). 


\section{ACKNOWLEDGEMENTS}

We are very grateful to Otso Suominen, Elina Vainio, Tommi Andersson and Ilkka Syvänperä at the Kevo Research Station (Finland) for facilitating our work in many ways. Victor van Dijk helped with collecting data in the field, Jan van Walsem assisted with nutrient analysis. We thank also the constructive criticism of Sarah Hobbie, Jonas Lembrechts and one anonymous reviewer. The research leading to these results has received funding from the European Union's Horizon 2020 project INTERACT, under Grant Agreement No. 730938 in 2013 and 2019, granted to MH and JL. Additional funding was received from the Dutch Schure-Beijerinck-Popping (2010-2011), a University of Helsinki Peatlanders Prize grant to $\mathrm{HV}$, and a Christine Buisman fund to IK. We thank the Norwegian Meteorological Institute for free access of their snow data for their lowlands station near Pulmankijärvi.

\section{DATA AVAILABILITY}

All data used for tables and figures in main text and in Supporting information are accessible at https://doi.org/10.17026/dans-xcx-rbyy.

\section{Compliance with Ethical Standards}

Conflict of interest The authors declare that they have no conflict of interest.

\section{OPEN ACCESS}

This article is licensed under a Creative Commons Attribution 4.0 International License, which permits use, sharing, adaptation, distribution and reproduction in any medium or format, as long as you give appropriate credit to the original author(s) and the source, provide a link to the Creative Commons licence, and indicate if changes were made. The images or other third party material in this article are included in the article's Creative Commons licence, unless indicated otherwise in a credit line to the material. If material is not included in the article's Creative Commons licence and your intended use is not permitted by statutory regulation or exceeds the permitted use, you will need to obtain permission directly from the copyright holder. To view a copy of this licence, visit http://creativecommons.org/ licenses/by/4.0/.

\section{REFERENCES}

Åkerman HJ, Johansson M. 2008. Thawing permafrost and thicker active layers in sub-Arctic Sweden. Permafr Periglac Process 19:279-92.

Anschlag K, Broll G, Holtmeier FK. 2008. Mountain birch seedlings in the treeline ecotone, subarctic Finland: variation in above-and below-ground growth depending on microtopography. Arct Antarct Alp Res 40:609-16.

Ballantyne M, Pickering CM. 2015. Shrub facilitation is an important driver of alpine plant community diversity and functional composition. Biodivers Conserv 24:1859-75.

Bates D, Maechler M, Bolker B, Steve W. 2015. Fitting linear mixed-effects models using lme4. J Stat Softw 67:1-48.

Betts RA. 2000. Offset of the potential carbon sink from boreal forestation by decreases in surface albedo. Nature 408:187-90.

Biskaborn BK, Smith SL, Noetzli J, Matthes H, Vieira G, Streletskiy DA, Schoeneich P, Romanovsky VE, Lewkowicz AG, Abramov A, Allard M, Boike J, Cable WL, Christiansen HH, Delaloye R, Diekmann B, Drozdov D, Etzelmüller B, Grosse G, Guglielmin M, Ingeman-Nielsen T, Isaksen K, Ishikawa $M$, Johansson $M$, Johannsson $H$, Joo A, Kaverin $D$, Kholodov A, Konstantinov P, Kröger T, Lambiel C, Lanckman J-P, Luo D, Malkova G, Meiklejohn I, Moskalenko N, Oliva M, Phillips M, Ramos M, Britta A, Sannel K, Sergeev D, Seybold C, Skryabin P, Vasiliev A, Wu Q, Yoshikawa K, Zheleznyak M, Lantuit H. 2019. Permafrost is warming at a global scale. Nat Commun 10:264-75.

Chapin FS, Sturm M, Serreze MC, McFadden JP, Key JR, Lloyd AH, McGuire AD, Rupp TS, Lynch AH, Schimel JP, Beringer J, Chapman WL, Epstein HE, Euskirchen ES, Hinzman LD, Jia G, Ping C-L, Tape KD, Thompson CDC, Walker DA, Welker JM. 2005. Role of land-surface changes in Arctic summer warming. Science 310:657-60.

Chen J, Yang Y, Wang S, Sun H, Schöb C. 2020. Shrub facilitation promotes selective tree establishment beyond the climatic treeline. Sci Total Environ 708:134618.

Crawley MJ, Ross GJS. 1990. The population dynamics of plants [and discussion]. Philos Trans Biol Sci 330:125-40.

De Frenne P, Rodríguez-Sánchez F, Coomes DA, Baeten L, Verstraeten G, Vellend M, Bernhardt-Römermann M, Brown CD, Brunet J, Cornelis J, Decocq GM. 2013. Microclimate moderates plant responses to macroclimate warming. Proc Natl Acad Sci 110:18561-5.

Dial RJ, Scott Smeltz T, Sullivan PF, Rinas CL, Timm K, Geck JE, Carl Tobin S, Golden TS, Berg EC. 2016. Shrubline but not treeline advance matches climate velocity in montane ecosystems of south-central Alaska. Glob Change Biol 22:1841-56.

Fronzek S, Carter TR, Räisänen J, Ruokolainen L, Luoto M. 2010. Applying probabilistic projections of climate change with impact models: a case study for sub-arctic palsa mires in Fennoscandia. Clim Change 99:515-34.

Frost GV, Epstein HE. 2013. Tall shrub and tree expansion in Siberian tundra ecotones since the 1960s. Glob Change Biol 20:1264-77.

García Criado M, Myers-Smith IH, Bjorkman AD, Lehmann CE, Stevens N. 2020. Woody plant encroachment intensifies under climate change across tundra and savanna biomes. Glob Ecol Biogeogr 29:925-43.

Goulden ML, Wofsy SC, Harden JW, Trumbore SE, Crill PM, Gower ST, Fries T, Daube BC, Fan S-M, Sutton DJ, Bazzaz A, 
Munger JW. 1998. Sensitivity of boreal forest carbon balance to soil thaw. Science 279:214-17.

Graae BJ, Alsos IG, Ejrnaes R. 2008. The impact of temperature regimes on development, dormancy breaking and germination of dwarf shrub seeds from arctic, alpine and boreal sites. Plant Ecol 198:275-84.

Hagedorn F, Shiyatov SG, Mazepa VS, Devi NM, Grigor'ev AA, Bartysh AA, Fomin VV, Kapralov DS, Terent'ev M, Bugman H, Rigling A, Moiseev PA. 2014. Treeline advances along the Urals mountain range-driven by improved winter conditions? Glob Change Biol 20:3530-43.

Hobbie SE, Chapin FS. 1998. An experimental test of limits to tree establishment in Arctic tundra. J Ecol 86:449-61.

Holmgren M, Scheffer M, Huston MA. 1997. The interplay of facilitation and competition in plant communities. Ecology 78:1966-75

Holmgren M, Lin CY, Murillo JE, Nieuwenhuis A, Penninkhof J, Sanders $\mathrm{N}$, van Bart $\mathrm{T}$, van Veen $\mathrm{H}$, Vasander $\mathrm{H}$, Vollebregt ME, Limpens J. 2015. Positive shrub-tree interactions facilitate woody encroachment in boreal peatlands. J Ecol 103:5866.

Holtmeier FK, Broll G. 2007. Treeline advance-driving processes and adverse factors. Landsc Online 1:1-33.

Hustig I. 1953. The boreal limits of conifers. Arctic 6:149-62.

IPCC. 2019. Summary for policymakers. In: Pörtner HO, Roberts DC, Masson-Delmotte V, Zhai P, Tignor M, Poloczanska E, Mintenbeck K, Alegría A, Nicolai M, Okem A, Petzold J, Rama B, Weyer N, Eds. IPCC Special report on the ocean and cryosphere in a changing climate. IPCC-51, in press.

Jorgenson MT, Racine CH, Walters JC, Osterkamp TE. 2001. Permafrost degradation and ecological changes associated with a warming climate in central Alaska. Clim Change 48:551-79.

Kéfi S, Holmgren M, Scheffer M. 2016. When can positive interactions cause alternative stable states in ecosystems? Funct Ecol 30:88-97.

Limpens J, van Egmond E, Li B, Holmgren M. 2014. Do plant traits explain tree seedling survival in bogs? Funct Ecol 28:283-90.

Lloyd AH, Yoshikawa K, Fastie CL, Hinzman L, Fraver M. 2003. Effects of permafrost degradation on woody vegetation at arctic treeline on the Seward Peninsula, Alaska. Permafr Periglac Process 14:93-101.

Loranty MM, Abbott BW, Blok D, Douglas TA, Epstein HE, Forbes BC, Jones BM, Kholodov AL, Kropp H, Malhotra A, Mamet SD, Myers-Smith IH, Natali SM, O'Donnell JA, Phoenix GK, Rocha AV, Sonnentag O, Tape KD, Walker DA. 2018. Reviews and syntheses: changing ecosystem influences on soil thermal regimes in northern high-latitude permafrost regions. Biogeosciences 15:5287-313.

Luoto M, Seppälä M. 2002. Characteristics of earth hummocks (pounus) with and without permafrost in Finnish Lapland. Geogr Ann Ser A Phys Geogr 84:127-36.

Luoto M, Seppälä M. 2003. Thermokarst ponds as indicators of the former distribution of palsas in Finnish Lapland. Permafr Periglac Process 14:19-27.

Mack MC, Bret-Harte MS, Hollingsworth TN, Jandt R, Schuur EAG, Shaver GR, Verbyla DL. 2011. Carbon loss from an unprecedented Arctic tundra wildfire. Nature 475:489-92.

Malfasi F, Cannone N. 2020. Climate warming persistence triggered tree ingression after shrub encroachment in a high al- pine tundra. Ecosystems. https://doi.org/10.1007/s10021020-00495-7.

Malmer N, Johansson T, Olsrud M, Christensen TR. 2005. Vegetation, climatic changes and net carbon sequestration in a North-Scandinavian subarctic mire over 30 years. Glob Change Biol 11:1895-909.

Mamet SD, Chun KP, Kershaw GG, Loranty MM, Peter Kershaw G. 2017. Recent increases in permafrost thaw rates and areal loss of palsas in the Western Northwest Territories, Canada. Permafr Periglac Process 28:619-33.

McGuire AD, Chapin Iii FS, Walsh JE, Wirth C. 2006. Integrated regional changes in Arctic climate feedbacks: implications for the global climate system. Annu Rev Environ Resour 31:6191.

Merkouriadi I, Leppäranta M, Järvinen O. 2017. Interannual variability and trends in winter weather and snow conditions in Finnish Lapland. Est J Earth Sci 66:47-57.

Milbau A, Graae BJ, Shevtsova A, Nijs I. 2009. Effects of a warmer climate on seed germination in the subarctic. Ann Bot 104:287-96.

Myers-Smith IH, Forbes BC, Wilmking M, Hallinger M, Lantz T, Blok D, Tape KD, Macias-Fauria M, Sass-Klaassen U, Lévesque E, Boudreau S, Ropars P, Hermanutz L, Trant A, Collier LS, Weijers S, Rozema J, Rayback SA, Schmidt NM, SchaepmanStrub G, Wipf S, Rixen C, Ménard CB, Venn S, Goetz S, Andreu-Hayles L, Elmendorf S, Ravolainen V, Welker J, Grogan P, Epstein HE, Hik DS. 2011. Shrub expansion in tundra ecosystems: dynamics, impacts and research priorities. Environ Res Lett 6:045509.

Myers-Smith IH, Hik DS. 2013. Shrub canopies influence soil temperatures but not nutrient dynamics: an experimental test of tundra snow-shrub interactions. Ecol Evol 3:3683-700.

Myers-Smith IH, Elmendorf SC, Beck PS, Wilmking M, Hallinger M, Blok D, Tape KD, Rayback SA, Macias-Fauria M, Forbes BC. 2015. Climate sensitivity of shrub growth across the tundra biome. Nat Clim Change 5:887-91.

Nauta AL, Heijmans MM, Blok D, Limpens J, Elberling B, Gallagher A, Li B, Petrov RE, Maximov TC, Van Huissteden J, Berendse F. 2015. Permafrost collapse after shrub removal shifts tundra ecosystem to a methane source. Nat Clim Change 5:67-70.

Olefeldt D, Goswami S, Grosse G, Hayes D, Hugelius G, Kuhry P, McGuire AD, Romanovsky VE, Sannel AB, Schuur EA, Turetsky MR. 2016. Circumpolar distribution and carbon storage of thermokarst landscapes. Nat Commun 7:13043.

Payette S, Delwaide A, Caccianiga M, Beauchemin M. 2004 Accelerated thawing of subarctic peatland permafrost over the last 50 years. Geophys Res Lett 31 .

Qian P, Schoenau JJ, Huang WZ. 1992. Use of ion exchange membranes in routine soil testing. Commun Soil Sci Plant Anal 23:1791-804.

Rupp TS, Chapin FS, Starfield AM. 2000. Response of subarctic vegetation to transient climatic change on the Seward Peninsula in north-west Alaska. Glob Change Biol 6:541-55.

Scheffer M, Hirota M, Holmgren M, Van Nes EH, Chapin FS. 2012. Thresholds for boreal biome transitions. Proc Natl Acad Sci 109:21384-9.

Schuur EA, Crummer KG, Vogel JG, Mack MC. 2007. Plant species composition and productivity following permafrost thaw and thermokarst in Alaskan tundra. Ecosystems 10:28092. 
Schuur EA, McGuire AD, Schädel C, Grosse G, Harden J, Hayes DJ, Hugelius G, Koven CD, Kuhry P, Lawrence DM. 2015. Climate change and the permafrost carbon feedback. Nature 520:171-9.

Sirois L. 2000. Spatiotemporal variation in black spruce cone and seed crops along a boreal forest-tree line transect. Can J For Res 30:900-9.

Smith WK, Germino MJ, Hancock TE, Johnson DM. 2003. Another perspective on altitudinal limits of alpine timberlines. Tree Physiol 23:1101-12.

Sollid JL, Sørbel L. 1998. Palsa bogs as a climate indicator: examples from Dovrefjell, southern Norway. Ambio 27:28791.

Sturm M, Schimel J, Michaelson G, Welker JM, Oberbauer SF, Liston GE, Fahnestock J, Romanovsky VE. 2005. Winter biological processes could help convert arctic tundra to shrubland. BioScience 55:17-26.

Suggit A, Gillingham PK, Hill JK, Huntley B, Kunin WE, Roy DB, Thomas CD. 2011. Habitat microclimates drive fine-scale variation in extreme temperatures. Oikos 120:1-8.

Swindles GT, Morris PJ, Mullan D, Watson EJ, Turner TE, Roland P, Amesbury MJ, Kokfelt U, Schoning K, Pratte S, Gallego-Sala A, Charman DJ, Sanderson N, Garneau M, Carrivick JL, Woulds C, Holden J, Parry L, Galloway JM. 2016. The long-term fate of permafrost peatlands under rapid climate warming. Sci Rep 5:17951.

Tape KEN, Sturm M, Racine C. 2006. The evidence for shrub expansion in northern Alaska and the Pan-Arctic. Glob Change Biol 12:686-702.
Tarnocai C, Canadell JG, Schuur EAG, Kuhry P, Mazhitova G, Zimov S. 2009. Soil organic carbon pools in the northern circumpolar permafrost region. Glob Biogeochem Cycles 23.

Virkkala R, Heikkinen RK, Leikola N, Luoto M. 2008. Projected large-scale range reductions of northern-boreal land bird species due to climate change. Biol Conserv 141:1343-53.

Waelbroeck C, Monfray P, Oechel WC, Hastings S, Vourlitis G. 1997. The impact of permafrost thawing on the carbon dynamics of tundra. Geophys Res Lett 24:229-32.

Walck JL, Hidayati SN, Dixon KW, Thompson KEN, Poschlod P. 2011. Climate change and plant regeneration from seed. Glob Change Biol 17:2145-61.

Wang P, Limpens L, Mommer L, van Ruijven J, Nauta AL, Berendse F, Schaepman-Strub G, Blok D, Maximov TC, Heijmans MMPD. 2017. Above-and below-ground responses of four tundra plant functional types to deep soil heating and surface soil fertilization. J Ecol 105:947-57.

Xu C, Van Nes EH, Holmgren M, Kéfi S, Scheffer M. 2015. Local facilitation may cause tipping points on a landscape level preceded by early-warning indicators. Am Nat 186:81-90.

Zeh L, Limpens J, Erhagen B, Bragazza L, Kalbitz K. 2019. Plant functional types and temperature control carbon input via roots in peatland soils. Plant Soil 438:19-38.

Zhang W, Miller PA, Smith B, Wania R, Koenigk T, Döscher R. 2013. Tundra shrubification and tree-line advance amplify arctic climate warming: results from an individual-based dynamic vegetation model. Environ Res Lett 8:034023. 